\title{
Methadone adverse reaction presenting with large increase in plasma methadone binding: a case series
}

Wenjie J Lu*, Weidong Zhou², Yvonne Kreutz ${ }^{3}$ and David A Flockhart ${ }^{1,3}$

\begin{abstract}
Introduction: The use of methadone as an analgesic is on the increase, but it is widely recognized that the goal of predictable and reproducible dosing is confounded by considerable variability in methadone pharmacokinetics, and unpredictable side effects that include sedation, respiratory depression and cardiac arrhythmias. The mechanisms underlying these unpredictable effects are frequently unclear. Here, to the best of our knowledge we present the first report of an association between accidental methadone overexposure and increased plasma protein binding, a new potential mechanism for drug interactions with methadone.
\end{abstract}

Case presentation: We describe here the cases of two patients who experienced markedly different responses to the same dose of methadone during co-administration of letrozole. Both patients were post-menopausal Caucasian women who were among healthy volunteers participating in a clinical trial. Under the trial protocol both patients received $6 \mathrm{mg}$ of intravenous methadone before and then after taking letrozole for seven days. One woman (aged 59) experienced symptoms consistent with opiate overexposure after the second dose of methadone that were reversed by naloxone, while the other (aged 49) did not. To understand the etiology of this event, we measured methadone pharmacokinetics in both patients. In our affected patient only, a fourfold to eightfold increase in methadone plasma concentrations after letrozole treatment was observed. Detailed pharmacokinetic analysis indicated no change in metabolism or renal elimination in our patient, but the percentage of unbound methadone in the plasma decreased 3.7-fold. As a result, the volume of distribution of methadone decreased approximately fourfold. The increased plasma binding in our affected patient was consistent with observed increases in plasma protein concentrations.

Conclusions: The marked increase in the total plasma methadone concentration observed in our patient, and the enhanced pharmacodynamic effect, appear primarily due to a reduced volume of distribution. The extent of plasma methadone binding may help to explain the unpredictability of its pharmacokinetics. Changes in volume of distribution due to plasma binding may represent important causes of clinically meaningful drug interactions.

\section{Introduction}

The use of methadone as an analgesic is on the increase [1], but it is widely recognized that the goal of predictable and reproducible dosing is confounded by considerable variability in methadone pharmacokinetics $[2,3]$. The unpredictability of methadone's effects results in a high incidence of inappropriate overdosing and underdosing, which can lead to severe adverse events including

\footnotetext{
* Correspondence: lu20@iupui.edu

'Division of Clinical Pharmacology, Department of Pharmacology and

Toxicology, Indiana University School of Medicine, Indianapolis, Indiana, USA

Full list of author information is available at the end of the article
}

sedation, respiratory depression and cardiac arrhythmias [4-6]. Many such events, including death, occur beyond the reach of medical care or observation. As a result a complete understanding of the mechanisms underlying individual adverse events has rarely been possible. We present here a scenario in which we were able to carefully investigate the cause of an accidental methadone overexposure. To the best of our knowledge this is the first report of an association between accidental methadone overexposure and increased plasma protein binding.

\section{Biomed Central}

(C) 2011 Lu et al; licensee BioMed Central Ltd. This is an Open Access article distributed under the terms of the Creative Commons Attribution License (http://creativecommons.org/licenses/by/2.0), which permits unrestricted use, distribution, and reproduction in any medium, provided the original work is properly cited. 


\section{Case presentation}

We describe here the cases of two patients who experienced markedly different responses to the same dose of methadone during co-administration of letrozole. Both patients were post-menopausal Caucasian women who were among healthy volunteers participating in a clinical trial (depicted in Table 1). The protocol for this study was approved by the Indiana University School of Medicine Institutional review Board (IRB), both patients signed informed consent before participation in the trial, and all procedures were conducted in accordance with the guidelines of the Declaration of Helsinki. The trial was designed to test the hypothesis that the aromatase inhibitor, letrozole, would alter the pharmacokinetics of methadone, based on pre-clinical data indicating that methadone is metabolized by aromatase in vitro [7]. Under the trial protocol both patients received $6 \mathrm{mg}$ of intravenous methadone before, and then after taking letrozole for seven days.

\section{Case 1}

Our first patient was a 49-year-old Caucasian woman (69.5 $\mathrm{kg}$, body mass index (BMI) 27.3, taking naproxen) who responded normally to the administered drugs as expected, and did not show any clinical adverse reaction to methadone or letrozole throughout the course of study. We designated this unaffected patient as ' $\mathrm{N}$ ', and the doses of methadone administered before and after letrozole as dose ' $A$ ' and dose ' $B$ ' in the subsequent data analyses in order to compare the results between the two patients. All plasma and urine samples collected were analyzed as described in Additional file 1. No significant change in methadone pharmacokinetics before and after letrozole treatment was observed in our patient. Pharmacokinetic data obtained from patient ' $\mathrm{N}$ ' were compared to those from Case 2 in details as described below.

\section{Case 2}

Our second patient was a 59-year-old Caucasian woman (86.8 kg, BMI 29.2, taking vitamin C, D, E, B6 and calcium). She experienced symptoms consistent with opiate overexposure that were reversed by naloxone after the second dose of methadone. Specific details of this adverse event, including the hospital course, patient monitoring data and medication schedule that resulted are illustrated in Figure 1. We designated our patient, who had experienced the adverse reaction, as 'ADR', and the doses of methadone administered before and after letrozole as dose ' $C$ ' and dose ' $D$ ' in the subsequent data analyses. Pharmacokinetic data from our ADR patient were compared in detail to those obtained from our $\mathrm{N}$ patient.

No methadone was detected in the plasma before the administration of intravenous methadone at baseline to either patient. Methadone plasma concentrations in ADR after dose D were fourfold to eightfold higher than those measured after her methadone dose $C$, given in the absence of letrozole (Figure 2). The maximum concentration observed was $135 \mathrm{ng} / \mathrm{mL}$ after dose $\mathrm{D}$, while it was $30 \mathrm{ng} / \mathrm{mL}$ after dose $\mathrm{C}$. When estimated pharmacokinetic parameters in our two patients were compared, the area under the curve (AUC) $)_{0-24 h}$ of methadone, its redistribution half-life, and its volume of distribution $\left(V_{d}\right)$ were remarkably different after dose $\mathrm{D}$ in our ADR patient when compared to doses $\mathrm{A}, \mathrm{B}$ and $\mathrm{C}$ (Table 2). These data indicate that there was a fourfold to sixfold decrease in $V_{d}$ in our ADR patient after dose D.

The first 12-hour urine volume was much lower in ADR (dose D; Table 3). The concentration of urinary methadone after dose D was approximately 13 -fold higher than that after dose $\mathrm{C}$, and the total amount of methadone excreted was 1.4-fold greater.

The metabolite data from our ADR patient also indicate important differences after dose $\mathrm{D}$, both in the plasma (Table 2) and in the urine (Table 3). The $\mathrm{AUC}_{0-}$ $24 \mathrm{~h}$ of plasma 2-ethylidene-1,5-dimethyl-3,3-diphenylpyrrolidine (EDDP; primary metabolite of methadone) and 2-ethyl-5-methyl-3,3-diphenyl-1-pyrroline (EMDP; secondary metabolite of methadone) increased approximately eightfold and approximately sevenfold respectively. The urinary concentration of EDDP increased approximately 17 -fold, and the concentration of EMDP

Table 1 Clinical trial design and schedule of activities

\begin{tabular}{|c|c|c|c|c|c|c|c|c|c|c|c|c|c|c|c|c|c|c|c|}
\hline \multirow[b]{2}{*}{ Study day } & \multirow{2}{*}{$\begin{array}{l}\text { Screening } \\
-28 \text { to } 0\end{array}$} & \multicolumn{4}{|c|}{ Period I } & \multicolumn{8}{|c|}{ Washout period } & \multicolumn{6}{|c|}{ Period II } \\
\hline & & 01 & 02 & 03 & 04 & 05 & 06 & 07 & 08 & 09 & 10 & 11 & 12 & 13 & 14 & 15 & 16 & 17 & 18 \\
\hline Electrocardiogram for QT interval & $x$ & & & & & & & & & & & & & & & & & & \\
\hline Blood draw for screening & $x$ & & & & & & & & & & & & & & & & & & \\
\hline Methadone dose, 6.0 mg, intravenous & & $x$ & & & & & & & & & & & & & & $x$ & & & \\
\hline Letrozole dose, 2.5 mg, orally once a day & & & & & & & & & $x$ & $x$ & $x$ & $x$ & $x$ & $x$ & $x$ & $x$ & $x$ & $x$ & $x$ \\
\hline Blood draw for pharmacokinetics & & $x$ & $x$ & $x$ & $x$ & & & & & & & & & & & $x$ & $x$ & $x$ & $x$ \\
\hline Urine sampling & & $x$ & & & & & & & & & & & & & & $x$ & & & \\
\hline
\end{tabular}

Blood samples (10 mL each) were collected before and at one, two, four, eight, 12, 24, 48 and 72 hours after each methadone dose, except in the second dose for our affected patient from whom blood samples at 48 and 72 hours could not be collected. Urine samples were collected at baseline and over the first 12 hours after methadone dose. 


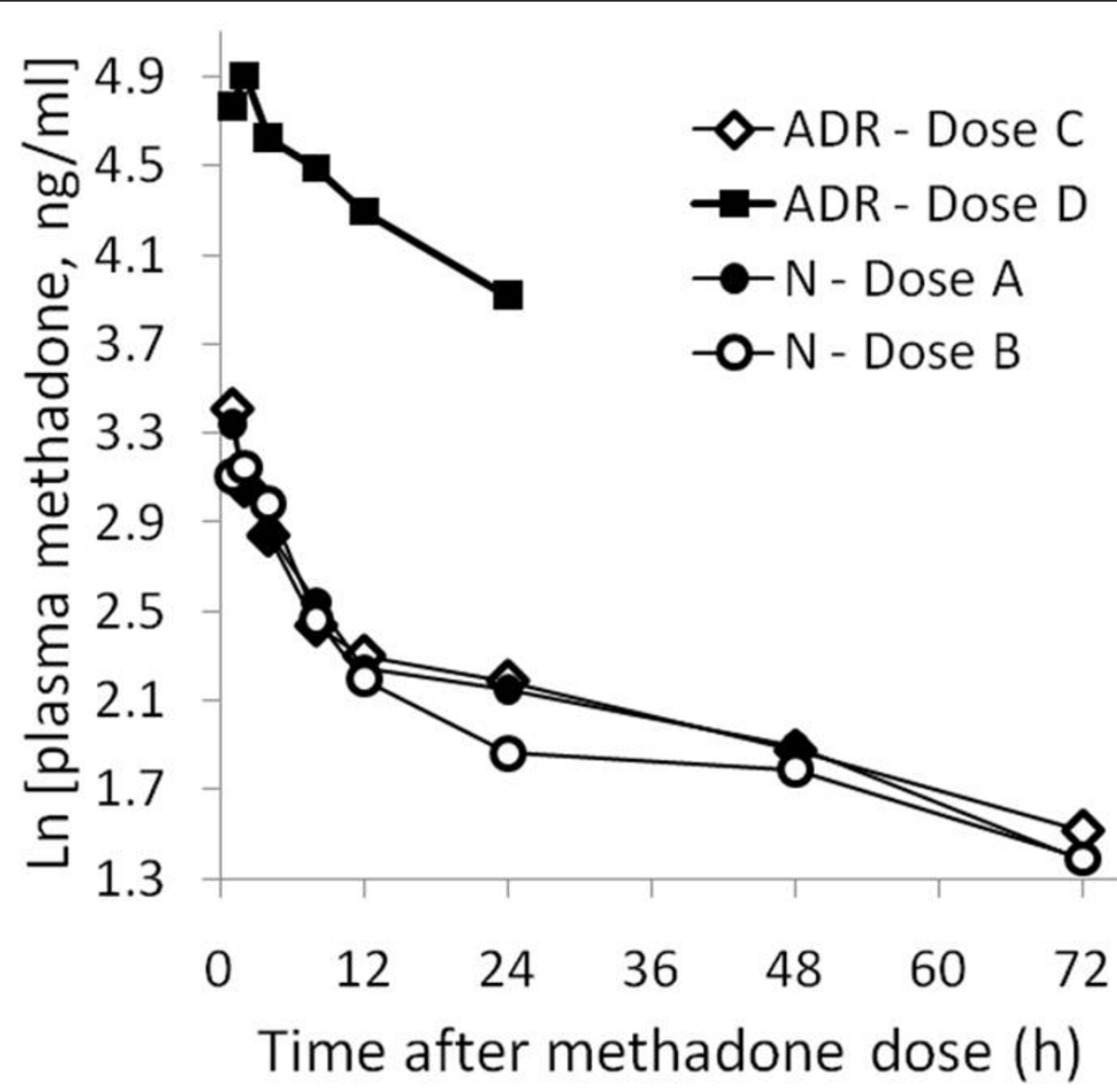

Figure 1 Course of the adverse event over the first five hours after the dose of methadone. The white arrows under the name of each medication indicate their times of administration. Shaded boxes on lines following specific symptoms indicate the times and duration of those symptoms. Double-headed arrow: during this time, vital signs worsened. The lowest blood pressure recorded was 110/86, respiratory rates as low as five breaths/minute occurred, and pulse oximetry documented oxygen saturation as low as 75\%.

\begin{tabular}{|c|c|c|c|c|c|}
\hline \multicolumn{6}{|c|}{ Medications prior to study Day 15: letrozole, $2.5 \mathrm{mg}$ PO QD for 7 days } \\
\hline \multirow{2}{*}{$\begin{array}{l}\text { Medication } \\
\text { administered on } \\
\text { study Day } 15\end{array}$} & Methadone & Ondansetron & Naloxone & Metoclopramide & \\
\hline & 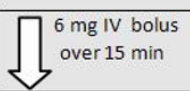 & $\left.\begin{array}{r}4 \mathrm{mg} \\
\text { IV push }\end{array}\right]$ & $\left\{\begin{array}{l}0.4 \mathrm{mg} \mathrm{IV} \\
\text { bolus over } \\
2 \mathrm{~min}\end{array}\right.$ & 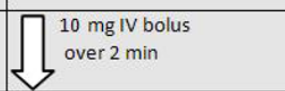 & \\
\hline $\begin{array}{c}\text { Time after } \\
\text { methadone }(\mathrm{h})\end{array}$ & \multicolumn{2}{|l|}{0} & 2 & 4 & 5 \\
\hline \multicolumn{6}{|l|}{ Nausea } \\
\hline \multicolumn{6}{|l|}{ Respiratory depression } \\
\hline \multicolumn{6}{|l|}{ Drowsiness } \\
\hline \multicolumn{6}{|l|}{ Hypotension } \\
\hline \multicolumn{6}{|l|}{ Headache } \\
\hline $\begin{array}{l}\text { Figure } 2 \text { Plasma meth } \\
\text { experienced methadone } \\
\text { of methadone administer }\end{array}$ & $\begin{array}{l}\text { ne concentratio } \\
\text { exposure; doses } \\
\text { fter letrozole trea }\end{array}$ & $\begin{array}{l}\text { fter single intra } \\
C=\text { doses of } m \\
\text { ti } N=\text { our unaffe }\end{array}$ & $\begin{array}{l}\text { doses admi } \\
\text { e administerec } \\
\text { tient. }\end{array}$ & $\begin{array}{l}\text { tered to both patients } \\
\text { efore letrozole treatment; }\end{array}$ & $\begin{array}{l}\text { nt who } \\
\text { doses }\end{array}$ \\
\hline
\end{tabular}


Table 2 Plasma pharmacokinetic parameters

\begin{tabular}{|c|c|c|c|c|c|c|}
\hline \multirow[t]{2}{*}{ Parameter } & \multicolumn{3}{|l|}{$\mathrm{N}$} & \multicolumn{3}{|l|}{ ADR } \\
\hline & Dose A & Dose B & Ratio (B/A) & Dose C & Dose D & Ratio $(D / C)$ \\
\hline Letrozole $C_{\text {baseline }}(\mathrm{ng} / \mathrm{mL})$ & 0 & 106.9 & & 0 & 76.1 & \\
\hline \multicolumn{7}{|l|}{ Methadone } \\
\hline $\mathrm{AUC}_{0-24 \mathrm{~h}}(\mathrm{ng} / \mathrm{hour} / \mathrm{mL})$ & 288.5 & 272.2 & 0.94 & 291.2 & 1857 & 6.4 \\
\hline$A \cup C_{\text {inf }}(\mathrm{ng} /$ hour/mL) & 879.8 & 833.1 & 0.95 & 946.0 & $5674^{a}$ & 6.0 \\
\hline Distribution $\mathrm{T}_{1 / 2}$ (hour) & 8.3 & 7.0 & 0.84 & 6.7 & 15.5 & 2.3 \\
\hline Elimination $\mathrm{T}_{1 / 2}$ (hour) & 48.5 & 50.4 & 1.0 & 52.4 & $52.4^{a}$ & 1.0 \\
\hline Clearance (L/hour) & 6.8 & 7.2 & 1.1 & 6.3 & $1.1^{\mathrm{a}}$ & 0.17 \\
\hline$\overline{V_{d \text { (extrap) }}(L)}$ & 516.6 & 557.4 & 1.1 & 502.9 & $119.2^{b}$ & 0.24 \\
\hline $\mathrm{V}_{\mathrm{d} \text { (area) }}(\mathrm{L})$ & 476.9 & 524.3 & 1.1 & 469.0 & $80.0^{\mathrm{a}}$ & 0.17 \\
\hline \multicolumn{7}{|l|}{$\overline{\mathrm{EDDP}}$} \\
\hline $\mathrm{AUC}_{0-24 \mathrm{~h}}(\mathrm{ng} / \mathrm{hour} / \mathrm{mL})$ & 29.2 & 26.9 & 0.92 & 28.2 & 217.6 & 7.7 \\
\hline Observed $C_{\max }(\mathrm{ng} / \mathrm{mL})$ & 1.6 & 1.3 & 0.81 & 1.6 & 10.5 & 6.6 \\
\hline 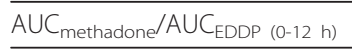 & 12.3 & 13.6 & 1.1 & 12.6 & 11.6 & 0.92 \\
\hline $\mathrm{A} \cup C_{\text {methadone }} / \mathrm{AUC}_{\text {EDDP }(0-24 \mathrm{~h})}$ & 9.9 & 10.1 & 1.0 & 10.3 & 8.5 & 0.83 \\
\hline \multicolumn{7}{|l|}{ EMDP } \\
\hline$\overline{A \cup C_{0-24 ~ h}(\mathrm{ng} / \text { hour } / \mathrm{mL})}$ & 2.7 & 2.0 & 0.74 & 1.5 & 10.4 & 6.9 \\
\hline Observed $C_{\max }(\mathrm{ng} / \mathrm{mL})$ & 0.18 & 0.14 & 0.78 & 0.075 & 0.55 & 7.3 \\
\hline
\end{tabular}

astimated using clearance and half-life calculated from the terminal elimination phase.

${ }^{\mathrm{b}}$ Estimated using an extrapolation method based on the terminal elimination phase.

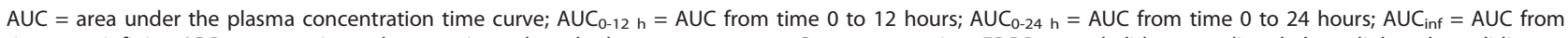
time 0 to infinity; $A D R=$ our patient who experienced methadone overexposure; $C=$ concentration; EDDP $=2$-ethylidene-1,5-dimethyl-3,3-diphenylpyrrolidine (primary metabolite of methadone); EMDP = 2-ethyl-5-methyl-3,3-diphenyl-1-pyrroline (secondary metabolite of methadone); $\mathrm{N}=$ our unaffected patient; $\mathrm{T}_{1 / 2}=$ half-life; $v_{d}=$ volume of distribution.

increased approximately 12 -fold. The total amounts of EDDP and EMDP excreted in urine during the first 12 hours were 1.8 -fold and 1.3-fold greater respectively than those after dose $\mathrm{C}$ (Table 3).

In order to determine the amount of bound and free methadone and EDDP in the plasma, we selected samples collected at eight and 12 hours after the methadone dose, which is after the redistribution phase assuming a twocompartment model. In our ADR patient, the mean methadone fraction unbound $\left(f_{u}\right)$ in these samples decreased 3.7-fold from doses $C$ to $D$, while the EDDP fraction unbound decreased 3.6-fold (Table 4).

\section{Table 3 Urinary pharmacokinetic parameters}

\begin{tabular}{|c|c|c|c|c|c|c|}
\hline \multirow[t]{2}{*}{ Parameter } & \multicolumn{3}{|l|}{$\mathbf{N}$} & \multicolumn{3}{|l|}{ ADR } \\
\hline & Dose A & Dose B & Ratio $(B / A)$ & Dose C & Dose D & Ratio $(D / C)$ \\
\hline Total urine volume (12 h, mL) & 3132 & 3090 & 0.99 & 2488 & 267 & 0.11 \\
\hline \multicolumn{7}{|l|}{ Methadone } \\
\hline$\overline{C(n g / m L)}$ & 52.6 & 54.6 & 1.0 & 88.6 & 1168 & 13.2 \\
\hline Total mass $(\mu \mathrm{g})$ & 165 & 169 & 1.0 & 220 & 312 & 1.4 \\
\hline Mass total $/ \mathrm{AUC}_{0-12 \mathrm{~h}}$ (L/hour) & 0.84 & 0.88 & 1.0 & 1.14 & 0.26 & 0.23 \\
\hline \multicolumn{7}{|l|}{ EDDP } \\
\hline$\overline{C(n g / m L)}$ & 12.7 & 8.97 & 0.71 & 25.5 & 424 & 16.6 \\
\hline Total mass $(\mu \mathrm{g})$ & 39.7 & 27.7 & 0.70 & 63.4 & 113 & 1.8 \\
\hline$\overline{C_{(\text {methadone) }} / C_{(\text {EDDP) }}}$ & 4.14 & 6.09 & 1.47 & 3.47 & 2.75 & 0.79 \\
\hline \multicolumn{7}{|l|}{$\overline{\text { EMDP }}$} \\
\hline $\mathrm{C}(\mathrm{ng} / \mathrm{mL})$ & 0.044 & 0.036 & 0.82 & 0.019 & 0.23 & 12.1 \\
\hline Total mass $(\mu \mathrm{g})$ & 0.14 & 0.11 & 0.79 & 0.047 & 0.062 & 1.3 \\
\hline
\end{tabular}

AUC = area under the plasma concentration time curve; $\mathrm{AUC}_{0-12 \mathrm{~h}}=\mathrm{AUC}$ from time 0 to 12 hours; $\mathrm{ADR}=$ our patient who experienced methadone overexposure; $C$ = concentration; EDDP = 2-ethylidene-1,5-dimethyl-3,3-diphenylpyrrolidine (primary metabolite of methadone); EMDP = 2-ethyl-5-methyl-3,3diphenyl-1-pyrroline (secondary metabolite of methadone); $\mathrm{N}=$ our unaffected patient. 
Table 4 Pharmacokinetic indices for plasma drug binding at eight and 12 hours after methadone dosing

\begin{tabular}{|c|c|c|c|c|c|}
\hline \multirow[t]{2}{*}{ Parameter } & \multicolumn{3}{|l|}{$\mathrm{N}$} & \multicolumn{2}{|l|}{ ADR } \\
\hline & Dose A & & Dose B & Dose C & Dose D \\
\hline \multicolumn{6}{|l|}{ Methadone } \\
\hline$C_{\text {free, }} 8 \mathrm{~h}(\mathrm{ng} / \mathrm{mL})$ & 1.40 & & 1.43 & 1.36 & 3.18 \\
\hline $\mathrm{C}_{\text {bound, } 8 \mathrm{~h}}(\mathrm{ng} / \mathrm{mL})$ & 8.45 & & 8.22 & 8.72 & 78.0 \\
\hline$C_{\text {free, } 12 \mathrm{~h}}(\mathrm{ng} / \mathrm{mL})$ & 1.18 & & 1.10 & 1.38 & 2.61 \\
\hline$C_{\text {bound, } 12 \mathrm{~h}}(\mathrm{ng} / \mathrm{mL})$ & 6.86 & & 6.74 & 7.40 & 58.8 \\
\hline Mean $f_{u}$ & 0.14 & & 0.14 & 0.15 & 0.04 \\
\hline$f_{u}$ ratio $(A / B$ or $C / D)$ & & 1.0 & & & \\
\hline$V_{d \text { (extrap) }}$ ratio & & 0.93 & & & \\
\hline$V_{\mathrm{d} \text { (area) }}$ ratio & & 0.91 & & & 9 \\
\hline \multicolumn{6}{|l|}{$\overline{\mathrm{EDDP}}$} \\
\hline $\mathrm{C}_{\text {free, } 8 \mathrm{~h}}(\mathrm{ng} / \mathrm{mL})$ & 0.38 & & 0.39 & 0.35 & 0.75 \\
\hline $\mathrm{C}_{\text {bound, } 8 \mathrm{~h}}(\mathrm{ng} / \mathrm{mL})$ & 0.72 & & 0.75 & 0.61 & 6.56 \\
\hline$C_{\text {free, } 12 \mathrm{~h}}(\mathrm{ng} / \mathrm{mL})$ & 0.36 & & 0.36 & 0.38 & 0.77 \\
\hline$C_{\text {bound, } 12 \mathrm{~h}}(\mathrm{ng} / \mathrm{mL})$ & 0.71 & & 0.66 & 0.69 & 7.37 \\
\hline Mean $f_{u}$ & 0.34 & & 0.35 & 0.36 & 0.10 \\
\hline$f_{u}$ ratio $(A / B$ or $C / D)$ & & 1.0 & & & 6 \\
\hline
\end{tabular}

$\mathrm{ADR}=$ our patient who experienced methadone overexposure; $\mathrm{C}=$ concentration; EDDP = 2-ethylidene-1,5-dimethyl-3,3-diphenylpyrrolidine (primary metabolite of methadone); $f_{u}=$ fraction unbound; $N=$ our unaffected patient.

When plasma protein concentrations were measured in these samples, an increase in total protein of 0.8 to $1.2 \mathrm{~g} /$ dL (13\% to $20 \%)$ was observed after dose D (Table 5). Upon further analysis of the whole plasma proteome by MS and relative quantification on the basis of label-free

Table 5 Plasma protein concentrations and serum chemistries at eight and $\mathbf{1 2}$ hours after methadone dosing

\begin{tabular}{|c|c|c|c|c|}
\hline \multirow[t]{2}{*}{ Parameter } & \multicolumn{2}{|l|}{$\mathbf{N}$} & \multicolumn{2}{|l|}{ ADR } \\
\hline & Dose A & Dose B & Dose C & Dose D \\
\hline \multicolumn{5}{|l|}{ Plasma proteins } \\
\hline Total protein $8 \mathrm{~h}(\mathrm{~g} / \mathrm{dL})$ & 5.8 & 5.8 & 5.9 & 7.1 \\
\hline Albumin $_{8} \mathrm{~h}(\mathrm{~g} / \mathrm{dL})$ & 3.4 & 3.5 & 3.4 & 3.8 \\
\hline$\overline{A A G_{8} h}(\mathrm{mg} / \mathrm{dL})$ & 84 & 86 & 74 & 87 \\
\hline Total protein $12 \mathrm{~h}(\mathrm{~g} / \mathrm{dL})$ & 6.3 & 6.0 & 6.1 & 6.9 \\
\hline Albumin $_{12 ~ h}(\mathrm{~g} / \mathrm{dL})$ & 3.5 & 3.5 & 3.6 & 3.8 \\
\hline $\mathrm{AAG}_{12 \mathrm{~h}}(\mathrm{mg} / \mathrm{dL})$ & 79 & 81 & 81 & 85 \\
\hline \multicolumn{5}{|l|}{ Serum chemistries } \\
\hline $\mathrm{Na}^{+}(\mathrm{mmol} / \mathrm{L})$ & & & 144 & 139 \\
\hline $\mathrm{Cl}^{-}(\mathrm{mmol} / \mathrm{L})$ & & & 108 & 104 \\
\hline $\mathrm{HCO}_{3}^{-}(\mathrm{mmol} / \mathrm{L})$ & & & 29 & 25 \\
\hline Blood urea nitrogen $(\mathrm{mg} / \mathrm{dL})$ & & & 15 & 15 \\
\hline Creatinine $(\mathrm{mg} / \mathrm{dL})$ & & & 0.78 & 0.72 \\
\hline
\end{tabular}

AAG $=\alpha_{1}$-acid glycoprotein; ADR $=$ our patient who experienced methadone overexposure; $\mathrm{N}=$ our unaffected patient. spectra count, proteins that appeared to increase by twofold to fourfold during the adverse event (dose $\mathrm{D}$ ) relative to samples drawn at the equivalent time before (dose C) included thrombin and its precursors, fibrinogen and its precursors, complement factor 1, retinol-binding protein 4, Shwachman-Bodian-Diamond syndrome protein, apolipoprotein A-IV, serpin peptidase inhibitor, clade $\mathrm{C}$ and kininogen 1 isoform 2 (data not shown).

In addition, serum concentrations of $\mathrm{Na}^{+}, \mathrm{Cl}^{-}, \mathrm{HCO}_{3}{ }^{-}$, blood urea nitrogen and creatinine in our ADR patient were similar after both doses C and D (Table 5). Serum lipid profiles were also similar before and after dosing (data not shown).

\section{Discussion}

No interaction between methadone and letrozole had been previously described. As a result of this adverse event, the investigators immediately informed the IRB, and put the trial on hold so that the cause of this adverse event could be carefully investigated before any adjustments were made to the trial design.

Unanticipated adverse events and fatalities caused by methadone are a significant public health problem [4-6]. In this case report, we observed a marked increase in plasma methadone concentrations and symptomatic overexposure during co-administration of letrozole to a single patient. Pharmacokinetic sampling was limited to the first 24 hours after methadone dosing during the adverse event, but large pharmacokinetic changes were obvious. Since such large intra-individual changes may have occurred in other patients, we estimated pharmacokinetic parameters in order to explore the multiple possible causes of this adverse reaction.

First, although the data appear similar to those that might be obtained as the result of a dosing error, the amount of methadone remaining (single vial) before and after this event were measured, and showed that the correct dose was used. The measured decrease in plasma $f_{u}$ also makes an overdose seem impossible.

Second, the increase in methadone exposure was not due to decreased metabolism, since the parent to metabolite ratio in both plasma and urine decreased in our patient.

Third, although the observed renal clearance of methadone significantly decreased (Table 3 ), reduced urinary clearance was not the cause of the pharmacokinetic changes observed in our patient since the total urinary drug excreted over 12 hours was higher rather than lower (Table 3).

Fourth, a small decrease in plasma volume could contribute to the total increase in drug concentrations, but serum electrolyte concentrations were similar after both methadone doses, suggesting our patient was not 
substantially hypovolemic. A small decrease in plasma volume cannot explain such large pharmacokinetic changes.

Fifth, a change in transporter activity could in theory increase plasma concentrations. The transport system involved would have to counteract the rapid tissue diffusion of methadone, a lipophilic drug, by stimulating active transport of drug back into the plasma. While this is theoretically possible, methadone has not been shown to be vulnerable to transporter-mediated interactions, and no effect of letrozole on drug transporters has ever been described previously.

Sixth, we did observe a greater than fourfold decrease in the estimated $V_{d}$ (Table 4), which could result in increased plasma and urine concentrations. $V_{d}$ can be described using the following equation:

$$
\mathrm{V}_{\mathrm{d}}=\mathrm{ECF}+\Phi \bullet f_{u} \bullet \mathrm{ICF}
$$

where ECF is the volume of the extra-cellular fluid, $\Phi$ is the tissue-binding factor, $f_{u}$ is the plasma fraction unbound, and ICF is the volume of the intra-cellular fluid [8]. Relative to the terms in the second half of the equation, ECF is a tiny contributor to the total $V_{d}$, especially for a drug with a large $V_{d}$ such as methadone [9]. A decrease in tissue binding would not be expected to reduce the $f_{u}$ in plasma, and cannot explain the increase in plasma binding actually observed. In contrast, we observed a decrease in $f_{u}$ due to increased plasma binding of methadone and its metabolites. A 3.7-fold change in $f_{u}$ is of similar scale to that in $\mathrm{V}_{\mathrm{d}}$, and therefore can account for most of the change. This change was also accompanied by an increase in free methadone concentration from 1.36 to $3.18 \mathrm{ng} / \mathrm{mL}$ in our affected patient. The concentration of bound methadone increased from 8.72 to $78.0 \mathrm{ng} / \mathrm{mL}$. While it is clear that the increased concentration of unbound methadone contributed to this symptomatic overexposure, the large change in bound methadone may also have contributed by making available a large reservoir of free drug for transport or diffusion across the blood brain barrier. In addition, we observed an increase in plasma protein concentrations, and this is consistent with the increase in plasma methadone binding. Of note, increased plasma protein concentration has been previously reported to result in decreased methadone $f_{u}$ [10].

Methadone has been shown to bind to a number of different plasma proteins [11,12], including $\alpha_{1}$-acid glycoprotein (AAG), $\beta$-globulin [11] and lipoprotein fractions [12]. When we examined changes in the plasma proteome after dose $\mathrm{D}$ relative to dose $\mathrm{C}$, we noted small increases in the concentrations of albumin and AAG, but prominent approximately twofold increases in proteins in the coagulation pathway: in concentrations of thrombin and its precursors, fibrinogen and its precursors and complement factor 1 . Which of these might be responsible for the change in methadone binding observed in our patient is at present unclear, but the suggestion that changes in the coagulation pathway may result in altered drug binding is an observation that may have significance in some clinical scenarios.

The observed change in binding could not have been due to the ingestion of other drugs, since neither of the women were taking any medicine known to alter methadone binding. It is possible that letrozole caused these changes in plasma protein concentrations via its effect on estrogen concentrations $[13,14]$. While few data are available on such effects of estrogen depletion, it is clear that estrogen supplementation with hormone replacement therapy can decrease the concentrations of AAG [15]. It follows that AAG may increase during therapy with an aromatase inhibitor, as was observed in this case. It is also possible that letrozole brings about these changes via an 'off-target' effect, or that the change we observed in methadone plasma binding is not due to letrozole, but due to some uncontrolled factor.

\section{Conclusions}

This study illustrates a novel mechanism underlying intra-individual changes in methadone pharmacokinetics and pharmacodynamics: increases in plasma binding that could result in increased effects. This mechanism might help explain the unpredictability of methadone effects. A similar mechanism may be responsible for interactions with other drugs that alter the concentrations of plasma binding proteins. The consequent changes in $V_{d}$ may represent important causes of clinically meaningful drug interactions.

\section{Consent}

Written informed consent was obtained from both patients for publication of this case report and any accompanying images. Copies of the written consents are available for review by the Editor-in-Chief of this journal.

\section{Additional material}

Additional file 1: Methods and materials. Supplementary materials

and methods.

\section{Acknowledgements}

The authors would like to thank Dr Zeruesenay Desta and Dr Richard Bergstrom from the Indiana University Division of Clinical Pharmacology for their help and advice during the conduct of these studies. This study is supported in part by the National Center for Research Resources (K24RR020815) and the National Institute for General Medical Sciences, (T32GM008425, U01GM061373) to DF. 


\section{Author details}

${ }^{1}$ Division of Clinical Pharmacology, Department of Pharmacology and Toxicology, Indiana University School of Medicine, Indianapolis, Indiana, USA. ${ }^{2}$ Center for Applied Proteomics and Molecular Medicine, George Mason University, Manassas, Virginia, USA. ${ }^{3}$ Division of Clinical Pharmacology, Department of Medicine, Indiana University School of Medicine, Indianapolis, Indiana, USA.

\section{Authors' contributions}

WL and DF participated in the design and conduct of the clinical trial, and are the major contributors in writing the manuscript. WL analyzed and interpreted the pharmacokinetic data on methadone and its metabolites. WZ carried out proteomic analysis on plasma samples. YK analyzed letrozole concentrations from plasma samples. All authors read and approved the final manuscript.

\section{Competing interests}

The authors declare that they have no competing interests.

Received: 28 April 2011 Accepted: 10 October 2011

Published: 10 October 2011

\section{References}

1. Fredheim OM, Moksnes K, Borchgrevink PC, Kaasa S, Dale O: Clinical pharmacology of methadone for pain. Acta Anaesthesiol Scand 2008, 52:879-889.

2. Weschules DJ, Bain KT, Richeimer S: Actual and potential drug interactions associated with methadone. Pain Med 2008, 9:315-344.

3. Totah RA, Sheffels P, Roberts T, Whittington D, Thummel K, Kharasch ED: Role of CYP2B6 in stereoselective human methadone metabolism. Anesthesiology 2008, 108:363-374.

4. Corkery JM, Schifano F, Ghodse AH, Oyefeso A: The effects of methadone and its role in fatalities. Hum Psychopharmacol 2004, 19:565-576.

5. Latowsky M: Methadone death, dosage and torsade de pointes: riskbenefit policy implications. J Psychoactive Drugs 2006, 38:513-519.

6. Modesto-Lowe V, Brooks D, Petry N: Methadone deaths: risk factors in pain and addicted populations. J Gen Intern Med 2010, 25:305-309.

7. Lu WJ, Bies R, Kamden LK, Desta Z, Flockhart DA: Methadone: a substrate and mechanism-based inhibitor of CYP19 (aromatase). Drug Metab Dispos 2010, 38:1308-1313.

8. Atkinson AJ Jr, Ruo TI, Frederiksen MC: Physiological basis of multicompartmental models of drug distribution. Trends Pharmacol Sci 1991, 12:96-101.

9. Inturrisi CE, Colburn WA, Kaiko RF, Houde RW, Foley KM: Pharmacokinetics and pharmacodynamics of methadone in patients with chronic pain. Clin Pharmacol Ther 1987, 41:392-401.

10. Garrido MJ, Aguirre C, Troconiz IF, Marot M, Valle M, Zamacona MK, Calvo R: Alpha 1-acid glycoprotein (AAG) and serum protein binding of methadone in heroin addicts with abstinence syndrome. Int $J$ Clin Pharmacol Ther 2000, 38:35-40.

11. Judis J: Binding of codeine, morphine, and methadone to human serum proteins. J Pharm Sci 1977, 66:802-806.

12. Romach MK, Piafsky KM, Abel JG, Khouw V, Sellers EM: Methadone binding to orosomucoid (alpha 1-acid glycoprotein): determinant of free fraction in plasma. Clin Pharmacol Ther 1981, 29:211-217.

13. Bajetta E, Ferrari L, Celio L, Mariani L, Miceli R, Di Leo A, Zilembo N, Buzzoni R, Spagnoli I, Martinetti A, Bichisao E, Seregni E: The aromatase inhibitor letrozole in advanced breast cancer: effects on serum insulinlike growth factor (IGF)-I and IGF-binding protein-3 levels. J Steroid Biochem Mol Biol 1997, 63:261-267.

14. Tahboub R, Arafah BM: Sex steroids and the thyroid. Best Pract Res Clin Endocrinol Metab 2009, 23:769-780.

15. Kremer JM, Wilting J, Janssen LH: Drug binding to human alpha-1-acid glycoprotein in health and disease. Pharmacol Rev 1988, 40:1-47.

doi:10.1186/1752-1947-5-513

Cite this article as: Lu et al: Methadone adverse reaction presenting with large increase in plasma methadone binding: a case series. Journal of Medical Case Reports 2011 5:513.

\section{Submit your next manuscript to BioMed Central and take full advantage of:}

- Convenient online submission

- Thorough peer review

- No space constraints or color figure charges

- Immediate publication on acceptance

- Inclusion in PubMed, CAS, Scopus and Google Scholar

- Research which is freely available for redistribution 